Port Econ J (2016) 15:199-214

DOI 10.1007/s10258-016-0123-8

\title{
Financial market development, global financial crisis and economic growth: evidence from developing nations
}

\author{
Rubi Ahmad ${ }^{1}$ \\ Oyebola Fatima Etudaiye-Muhtar ${ }^{1,2}$ \\ Bolaji Tunde Matemilola ${ }^{3}$ \\ Amin Noordin Bany-Ariffin ${ }^{3}$
}

Received: 6 August 2015 / Accepted: 30 August 2016/Published online: 8 September 2016

\# ISEG 2016

\begin{abstract}
Emerging and frontier markets in Africa have witnessed various economic and financial reforms aimed at integrating the domestic markets into the global financial market to attract investment. Whether these reforms promote high economic growth remains inconclusive. The paper applies the pooled mean group estimation technique to empirically re-investigate the link between financial market development, global financial crisis, and economic growth in selected African economies. The results strongly support our hypotheses that stock market and banking sector development promotes economic growth in the selected countries. Moreover, financial crisis reduce the positive effects of both the stock market and banking sector developments on economic growth. The study suggests that both the banking sector and stock market are important to deliver the long-run economic growth that the African region desired. Moreover, effort should be made to enact policy measures that would ensure development of the stock market which has received inadequate attention.
\end{abstract}

Keywords Financial development · Financial crisis - Dynamic heterogeneous panel · Growth · Africa

JEL classification $\mathrm{G} 10 \cdot \mathrm{O} 11 \cdot \mathrm{O} 16$

Bolaji Tunde Matemilola

matemilolabt@gmail.com

1 Department of Finance and Banking, University of Malaya, 50603 Kuala Lumpur, Malaysia

2 Department of Accounting and Finance, University of Ilorin, Ilorin, Nigeria

3 Faculty of Economics and Management, Universiti Putra Malaysia, 43400 Serdang, Malaysia 